\title{
The Use of English Before Swiss Courts: The Current Debate
}

\author{
Lorenz Raess *
}

In the aftermath of the Brexit referendum in 2016 and the withdrawal of the UK from the EU on 31 January 2020, several jurisdictions established so-called «international commercial courts», at which English is the standard language. Thus far, there have been few such initiatives in Switzerland. However, according to the ongoing revisions to both the Federal Act on International Private Law and the Swiss Civil Procedure Code, it is intended to allow the use of English in certain situations. Unsurprisingly, this has given rise to a wide-ranging debate in multilingual Switzerland. The present contribution outlines this discussion and proposes several practical solutions on how to deal with this delicate political issue.

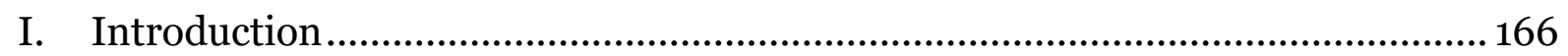

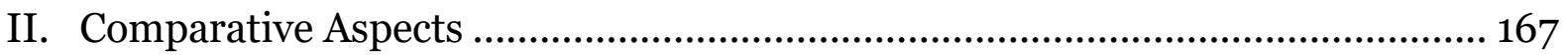

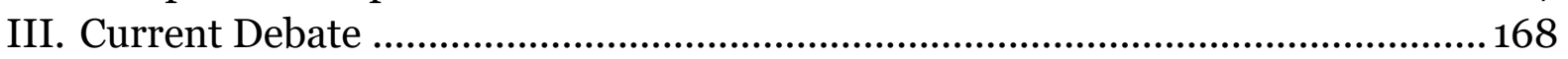

1. Federal Patent Court ............................................................................ 168

2. State Court Proceedings ....................................................................... 168

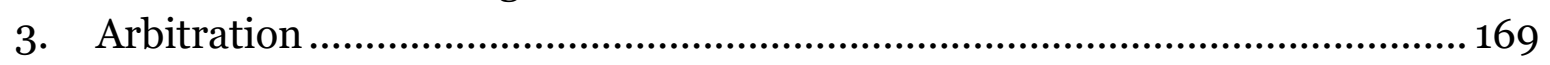

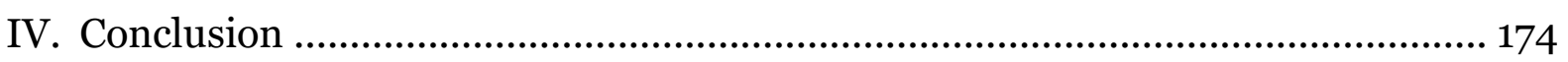

Citation: Lorenz Raess, The Use of English Before Swiss Courts: The Current Debate, in: sui-generis 2020, S. 165

URL: $\quad$ sui-generis.ch/128

DOI: $\quad$ https://doi.org/10.21257/sg.128

\footnotetext{
Attorney-at-law at Eversheds Sutherland (CH), lorenzraess@gmail.com. The author recently defended his dissertation entitled «Court Assistance in the Taking of Evidence in International Arbitration» (forthcoming 2020). He would like to thank Prof. Martin Beyeler, Prof. Ramon Mabillard, Dr. iur. Mark Schweizer and Joëlle Raess for their helpful comments on this article.
} 


\section{Introduction}

1 Beyond doubt, English is one of the languages that are most widely used by nonnative speakers around the world, and it still beats every other language by the total number of speakers. ${ }^{1}$ Often described as a lingua franca, ${ }^{2}$ it is used not only in everyday life but especially in international trade - and the many disputes arising from there. For this reason, English is used not only in courts in Englishspeaking countries but also in several international commercial courts around the globe which have been established in recent years. The goal of providing such specialized courts is that domestic companies engaging in cross-border transactions will resolve their disputes in a court and under the laws of their own country. 3

When focusing on Switzerland, two important milestones should be mentioned in this regard, at both the federal and cantonal level. First, according to the ongoing revision of the $12^{\text {th }}$ chapter of the Federal Act on International Private Law4 (IPLA CH) governing international arbitration, it is planned to allow legal submissions to be filed in English with the Federal Supreme Court (FSC), which usually acts as the sole appellate court for

1 The Ethnologue 200. However, this is mainly because English enjoys such popularity as a second language. For instance, far more people speak Mandarin Chinese as a first language than English; see Wikipedia.

2 A «lingua franca» may be defined as «any of various languages used as common or commercial tongues among peoples of diverse speech»; see the Merriam-Webster.com Dictionary.

3 Dorothee Ruckteschler/Tanja Stooss, International Commercial Courts: A Superior Alternative to Arbitration? Journal of International Arbitration 4/2019, 434.

4 Federal Act of 18 December 1987 on International Private Law, as amended on 1 January 2019 (IPLA CH; SR 291 [classified compilation of Swiss law]). both domestic and international arbitration proceedings. On 24 October 2018, the Federal Council published its dispatch and the parliamentary debates remain ongoing. While the National Council supported the novelty, the Council of States argued against it. 5 Thus, it remains uncertain if the two councils will reach a consensus in the subsequent resolution of differences procedure.

3 Second, the Swiss Civil Procedure Code 6 $(\mathrm{CPC} \mathrm{CH})$ governing cantonal state court proceedings is also under revision and has, among others, a similar goal: to create a legal basis at the cantonal level for the filing of legal submissions in English, where the parties agree to it. The Federal Council's dispatch was published on 26 February 2020, and the parliamentary debates are about to start shortly.

4 Thus far, the debates on the revision of the IPLA CH suggest that the proposed amendment is controversial; it is expected that the discussions on the revision of the $\mathrm{CPC} \mathrm{CH}$ will take a similar turn.

5 The present contribution aims to set out the pros and cons of using English in state court proceedings and weigh the various actors' interests (III). At the same time, several suggestions are made as to how the current issue might be addressed. As the debates on the revision of the $\mathrm{CPC} \mathrm{CH}$ have not yet begun, the focus is mainly on appellate proceedings in arbitral matters before the FSC. But first, a short comparative analysis (II) is re-

\footnotetext{
See the discussions in more detail.

6 Swiss Civil Procedure Code of 19 December 2008, as amended on 1 January 2020 (CPC CH; SR 272).
} 
quired, to put the present topic in an international context before focusing on the situation in Switzerland.

\section{Comparative Aspects}

6 The London Commercial Court has a long history of resolving cross-border disputes involving not only UK residents, but also continental Europeans, as the growing number of litigants from the region confirms.7 However, due to the UK's departure from the EU on 30 January 2020, important EU legislation in the field of international commercial law will soon cease to apply. As a consequence, the taking of evidence and the recognition and enforcement of decisions rendered by English courts in EU member states will become much more difficult. ${ }^{8}$ For this and other reasons, several European countries have taken the opportunity to establish international commercial courts with English as the applicable language of the proceedings. ${ }^{9}$

7 In Germany, although the official language is German,10 it has been possible since 2010 to conduct proceedings in English before the Cologne Higher Regional Court (Oberlandesgericht) and as-

\footnotetext{
See the Portland Commercial Courts Report 2019.

See e.g. EU Regulation 1215/2012 of 11 December 2012 on jurisdiction and the recognition and enforcement of judgments in civil and commercial matters; and EU Regulation 1206/2001 of 28 May 2001 on cooperation between the courts of the Member States in the taking of evidence in civil or commercial matters.

9 For similar developments outside the EU, see e.g. China International Commercial Court (established 2018); Singapore International Commercial Court (established 2015); Qatar International Court (established 2009); Dubai International Financial Centre Court (established 2004).

$10 \S 184$ German Court Constitution Act of 9 May 1975, as amended on 12 December 2019.
}

sociated regional courts in Cologne, Bonn and Aachen. Since 2018, this has also been an option at the regional courts of Frankfurt am Main and Hamburg, where specialised courts allow hearings in English upon the request of the parties. However, all formal submissions must be filed in German, and both the judgment and all procedural rulings and transcripts are rendered in German. ${ }^{11}$

8 In 2018 France followed suit: Both the Paris Commercial Court (Tribunal de commerce de Paris) and the Paris Court of Appeal (Paris Cour d'appel) changed their procedural rules to allow hearings and legal submissions in English. ${ }^{12}$ Here again, as the French Constitution ${ }^{13}$ states that the official language is French, the final decision is drafted in French. In contrast to the German approach, however, the final decision is accompanied by a sworn English translation, to facilitate its enforcement abroad. ${ }^{14}$ Another difference is that as the Paris Court of Appeal acts as the appellate court for decisions of the Paris Commercial Court, ${ }^{15}$ English may thus be used in two instances.

9 More recently, the Netherlands went one step further. On 1 January 2019, it established the Netherlands Commercial Court

11 Ruckteschler/Stoos, 437 (fn. 3); Giesela Rühl, Auf dem Weg zu einem europäischen Handelsgericht? Zum Wettbewerb der Justizstandorte in Zeiten des Brexit, Juristenzeitung 22/2018, 1076.

12 Protocol of the Paris Commercial Court of 7 February 2017; Protocol of the Paris Court of Appeal of 7 February 2018.

13 Art. 2 French Constitution of 4 October 1958, as amended in 2008.

14 Art. 7 Protocol of the Paris Commercial Court of 7 February 2017; Alexandre Biard, International Commercial Courts in France: Innovation without Revolution?, Erasmus Law Review 2019, 29; Rühl (fn. 11), 1077.

15 Art. 1.3 Protocol of the Paris Court of Appeal of 7 February 2018. 
as a separate chamber of the Regional Court of Amsterdam, whose decisions may be challenged before the Netherlands Commercial Court of Appeal. ${ }^{16}$ Unlike in Germany and France, English is the standard language of the proceedings, from submission of claims to final decision. ${ }^{17}$

\section{Current Debate}

\section{Federal Patent Court}

10 By contrast, Switzerland has been somewhat hesitant to take similar steps. At the federal level, it is only at the Federal Patent Court (FPC) that English is the standard language of proceedings. Art. 36 of the Patent Court Act, 18 which entered into force in 2012, states:

English may also be used provided that the court and the parties give their consent. The judgment and procedural rulings shall be drafted in one of the official languages in any event.

11 According to the FPC, it has never refused to conduct proceedings in English, as long as the parties have consented. Since its inauguration, the number of cases conducted in English has continu-

16 Friederike Henke, Netherlands Commercial Court - englischsprachige Gerichtsverfahren in den Niederlanden, RIW 2019, 273 et seqq.; Section 1.3.3. lit. a) Rules of Procedure for the International Commercial Chambers of the Amsterdam District Court (NCC District Court) and the Amsterdam Court of Appeal (NCC Court of Appeal) of December 2018.

17 Ibid., Section 2.1; Henke (fn. 16), 275; see also the first judgments of the Netherland Commercial Court.

18 Federal Act on the Federal Patent Court of 20 March 2009, as amended on 1 August 2018 (Patent Court Act; SR 173.41). ally increased; and since 2016, about $30 \%$ of all ordinary proceedings and $20 \%$ of summary proceedings have been held in English.19 In view of litigants' growing desire for full proceedings (i.e., also including the decision) to be conducted in English, the FPC has demanded for several years now that Art. 36 of the Patent Court Act should be amended accordingly - albeit without success thus far. ${ }^{20}$

\section{State Court Proceedings}

12 At the cantonal level, in a very early draft of the $\mathrm{CPC} \mathrm{CH}$ from 2003, the Federal Council proposed that the use of English in civil proceedings before cantonal courts should be permitted only if the parties and the court approve. ${ }^{21}$ However, this idea was ultimately abandoned and, according to the current Art. 129 $\mathrm{CPC} \mathrm{CH}$, proceedings must be conducted in the official language(s) of the respective canton. ${ }^{22}$

13 In 2018, when the current process of revising the $\mathrm{CPC} \mathrm{CH}$ commenced, the Federal Council showed itself willing to amend federal laws to enhance the attractiveness of Switzerland as a forum for the resolution of international commercial disputes. ${ }^{23}$ During the subsequent consultation process, the Zurich Bar Association proposed the establishment of a

19 FPC's annual reports from 2011-2019.

20 See e.g. the FPC's annual reports 2016 (81 et seq.) and 2017 (82).

21 Federal Council Dispatch about the Federal Code of Civil Procedure, 28 June 2006 (Federal Law Gazette 2006, 7221 et seqq., 7306).

22 Julia Gschwend, in: Basler Kommentar Zivilprozessordnung (ZPO), 2017, n. 4 of Art. 129.

23 Explanatory Report concerning the amendment of the Code of Civil Procedure of 2 March 2018, 15 et seq. 
legal basis, at both federal ${ }^{24}$ and cantonal25 level, for the creation of specialised commercial courts with English as the language of the proceedings. With the publication of its dispatch on 26 February 2020, the Federal Council followed these suggestions. Accordingly, the cantons may add separate chambers to their commercial courts, to which parties may resort directly in order to resolve international commercial disputes. ${ }^{26}$ It is also intended to introduce a second section to Art. 129 CPC CH stating:

Cantonal law may provide that if the parties so request, another national language or English may be used. ${ }^{27}$

14 In addition to this new possibility at the cantonal level, a draft of Art. 42(1 $\left.1^{\text {bis }}\right)$ of the Federal Supreme Court Act28 (FSCA $\mathrm{CH}$ ) reads as follows:

If the proceeding of the lower court has been conducted in English, legal submission can be filed in this language. ${ }^{29}$

15 These two amendments are intended to promote Switzerland as a forum for the resolution of international disputes by allowing the use of English throughout the cantonal and potential subsequent (federal) appellate proceedings. The cantons are not obliged to avail of this new

Opinion of the Zurich Bar Association, 1014 et seqq.

25 Postulate No 296/2018 of the Cantonal Parliament of Zurich.

26 Federal Council Dispatch about the Amendment of the Swiss Civil Procedure Code of 26 February 2020 (Federal Law Gazette 2020, 22, 33 et seqq).

27 Ibid., 49 et seqq.; translated by the author.

28 Federal Supreme Court Act of 17 June 2005, as amended on 1 January 2019 (FSCA CH; SR 173.110)

29 Ibid., 82 et seq.; translated by the author. option; it remains at their discretion to do so. It may be expected that this innovation will be of significant interest in cantons which play an important role in international commerce, such as Geneva and Zurich.

16 However, if the proposed amendments are enacted, there will be a divergence between cantonal and federal proceedings. At the cantonal level, the full proceedings may be conducted in English that is, including the legal submissions, the oral arguments in court and the final decision. Before the FSC, however, this would apply to the legal submissions only, as foreseen by the proposed amendment to appellate proceedings in arbitral matters (see infra III.3.a).30

17 It remains to be seen how the proposed amendments will be received in the upcoming debates of the Swiss Parliament. Even if they are enacted, it will remain at the cantons' discretion to avail of them; otherwise, the status quo will prevail.

\section{Arbitration}

\section{a) Introduction}

18 Unsurprisingly, in international arbitration, English is the predominant language of the proceedings. In 2018, for instance, it was used in over $80 \%$ of all recorded arbitrations under the International Chamber of Commerce and Swiss Rules. ${ }^{31}$ As long as the parties to the arbi-

30 Ibid., 50 et seq.

31 In the period from 2004-2018, English was the language of the proceedings in $70 \%$ of all cases; see SCAI Arbitration statistics of 2018; see also the latest ICC Dispute Resolution 2018 Statistics, according to which nearly $80 \%$ of all awards have been rendered in English, 15 . 
tration have chosen English as the applicable language of the proceedings and the arbitral award is not challenged, this fact has little consequence. However, if one of the parties tries to set aside the award, the legal submissions - that is, the objection itself and the attachments thereto - must be submitted in the language of the respective appellate court. In Switzerland, for instance, this would be one of the four official languages: German, French, Italian and in some rare cases Romansh. ${ }^{2}$

19 Given that the FSC usually acts as the sole appellate court for arbitral matters, an exception applies with regard to submitted attachments in a foreign language, which need not be translated if none of the parties objects. 33 However, the objection itself must be submitted in an official Swiss language as chosen by the parties and the FSC's final decision will be rendered in the same language. 34

In the proposed revisions to the IPLA CH, which governs international arbitral proceedings in Switzerland, the Federal Council has addressed this obstacle and intends to allow parties to submit not only the attachments but all legal submissions in English to the FSC. Since this

32 Art. 389 CPC CH; Art. 191 IPLA CH; Art. 70(1) Federal Constitution of the Swiss Confederation of 18 April 1999, as amended on 1 January 2020 (Const CH; SR 101); Art. 42 FSCA CH see also Decision of the Federal Supreme Court 4A_510/2017 of 9 November 2017.

33 Federal Council Dispatch About the Amendments of the IPLA CH (FCDisp IPLA CH), $12^{\text {th }} \mathrm{ch}$.: International Arbitration, 24 October 2018 (Federal Law Gazette 20187163 et seqq.), 7204 et seq.; Art. 54(3) FSCA CH; see also Decision of the Federal Supreme Court 4A_176/2008 of 23 September 2008 cons. 1.2.

34 Art. 42(1) FSCA CH; Decision of the Federal Supreme Court 4A_188/2016 of 11 January 2017, cons. 1; BGE 142 III 521, cons. 1. concerns proceedings before the $\mathrm{FSC}$, the FSCA CH would also have to be amended accordingly.

21 Because Art. 77 FSCA CH governs objections against both domestic and international arbitral awards, the amendment would also apply to domestic arbitration. At the time of writing (March 2020), the Swiss Parliament is debating a proposed new Art. 77(2 $\left.2^{\text {bis }}\right)$ FSCA CH, which reads as follows:

Legal submissions may be drafted in English. At the request and expense of a party, the Federal Supreme Court draws up an authenticated English translation of the fully executed decision which will be enclosed to the notice of the decision. 35

22 According to the Federal Council's rather brief reasoning, the first phrase aims to reduce the parties' translation burden by allowing for the use of English as the standard language in all arbitral proceedings in Switzerland, including appellate proceedings before the FSC. ${ }^{6}$ The National Council added the second phrase during parliamentary debates on 19 December 2019.37

23 Unsurprisingly, Art. 77(2 $\left.{ }^{\text {bis }}\right)$ FSCA CH received significant criticism very early in the consultation process, and there appears to be little consensus between arbitration practitioners and the FSC itself. 38

35 Translated by the author; FCDisp IPLA $\mathrm{CH}$ (fn. 33), 7204 et seq.

36 FCDisp IPLA CH (fn. 33), 7205.

37 See the Federal Council's Item No 18.076 .

38 Revision of the IPLA CH (International Arbitration), Report of the Result of the Consultation Procedure (Rep Consultation Procedure IPLA CH (2018) of 8 August 2018, 13. 
While supporters of the proposal (primarily Swiss law firms and several professors) 39 have emphasised that it should serve to promote Switzerland as a forum for arbitration, three core issues have been raised by the FSC, which are discussed below.

\section{b) Constitutional Concerns}

24 First, in the opening paragraph of its report on the IPLA CH's revision, the FSC flatly rejected the possibility of accepting legal submissions in English. ${ }^{\circ}$ It argued that - besides contradicting its own jurisprudence, as previously mentioned ${ }^{41}-$ the Swiss Constitution (Const CH) clearly states that Switzerland has four official languages. $4^{2}$ Therefore, Swiss citizens have not only a right but also a duty to use one of these languages when communicating with Swiss authorities which is even more so the case in relation to the FSC, Switzerland's highest judicial authority.43 For this reason, according to the FSC, in order to uphold the so-called «peace of languages» in Switzerland, no English submissions should be allowed, especially given the negligible interest of

$39 \overline{\text { See the Opinion of Organisations. For example, }}$ the Swiss Arbitration Association (28, n. 107 et seqq.); a group of Swiss law firms (123, n. 59 et seqq.); Swiss Holdings (202); University of Geneva (232) and the University of Lucerne (269, n. 81 et seqq.) are all strongly in favour of the proposed amendment.

40 Opinion of Organisations (fn. 39), 32.

41 See fn. 31 and fn. 32 supra.

42 Art. 70 Const. CH.

43 Opinion of Organisations, 32, with reference to Art. 188(1) Const CH; Eva Maria Belser/Bernhard Waldmann, in: Basler Kommentar Bundesverfassung, 2015, n. 15 of Art. 70 (cited: BSKBelser/Waldmann); see also Regula Kägi-Diener, in: Bundesverfassung St. Galler Kommentar, $3^{\text {rd }}$ ed. 2014, n. 17 of Art. 70 (cited: SGK-KägiDiener). the parties to the arbitration in reducing their translation costs. 44

25 It is true that the introduction of a new official language utilising a federal act would indeed represent a circumvention of the Const CH.45 However, it is also true that English is already de facto an essential language in certain areas of law. In addition, English is either one of several binding languages or even the sole binding language in several international treaties ${ }^{46}$. This does not seem to be at odds with Art. 70 Const $\mathrm{CH}$ in certain areas of law and for special legal relationships. For instance, at the Swiss Federal Institute of Technology in Zurich, the language of teaching and learning is English, in addition to the three main official languages. 47 Likewise, the standard language in radio-communications and air traffic is English. ${ }^{8}$ Legal authors such as Belser/Waldmann, Biaggini and KägiDiener therefore argue that as long as citizens are not forced to use an unofficial language, exceptions such as these do not seem to be in conflict with Art. 70 Const CH.49

44 Opinion of Organisations, 32 et seq.

45 BSK-Belser/Waldmann (fn. 43), n. 23 of Art. 70; SGK-Kägi-Diener (fn. 43), n. 18 of Art. 70.

46 See e.g. the double taxation agreement between Switzerland and the US, SR 0.672.933.61; or the investment treaty between Switzerland and Egypt, SR 0.975.232.1. For an extensive overview, see Max Baumann, Die Amtssprachen des Bundes sind Deutsch, Französisch, Italienisch und Englisch, SJZ 101/2005, 36 et seqq.

47 Federal Act on the Federal Institutes of Technology of 4 October 1991, as amended on 1 May 2017 (ETH Act; SR 414.110).

48 Art. 10a Civil Aviation Act of 21 December 1948, as amended on 1 January 2020 (SR 748.0).

49 BSK-Belser/Waldmann (fn. 43), n. 23 et seq. of Art. 70; SGK-Kägi-Diener (fn. 43), n. 18 of Art. 70; Givoanni Biaggini, in: BV Kommentar, Bundesverfassung der Schweizerischen Eidgenossenschaft, Orell Füssli Kommentar (OFK), $2^{\text {nd }}$ ed. 2017, n. 3 of Art. 70. 
Indeed, English as the language of appellate proceedings before the FSC in arbitral matters would be problematic only if the filing of legal submissions in English were mandatory. However, this is clearly not the case, since Art. 77(2 $\left.{ }^{\text {bis }}\right)$ FSCA CH is formulated as an optional provision.

27 This is confirmed by the fact that arbitration - perhaps as no other field of law is strongly dominated by the will of the parties. In most arbitrations, apart from investment or sports arbitration, the parties enter into an arbitration agreement based solely on their free will and without coercion. To allow legal submissions to be filed in English in a field of law where everything stands and falls on the will of the parties would facilitate the proceedings, rather than the opposite. It is thus clear that the proposed amendment only concerns a special field of law and a specific legal relationship - that is, the relationship between the parties of the arbitration.

For this reason, one might ask whether Art. 77(2 $2^{\text {bis}) ~ F S C A ~ C H ~ c o u l d ~ b e ~ c o o r d i-~}$ nated with the draft of Art.129(2) CPC $\mathrm{CH}$ (see supra II.2) as follows:

If the parties so request, English may also be used as the language of the proceedings.

29

Instead of merely allowing legal submissions to be filed in English, this would make clear that English is the governing language for the full proceedings, including the final decision. As public hearings at the FSC are very rare, and correspondence is effected exclusively in writing, this should pose no further problems.

\section{c) Translation Difficulties}

30 Second, the FSC questioned its ability to handle English cases in general.50 It not only doubted the English skills of its chancellery but also envisaged difficulties with legal terms and concepts if a court clerk had to copy English passages from the parties' legal submissions when drafting the decision in one of the official languages. In the same vein, Mabillard rightly points out that translations of legal texts are «not purely linguistic translations».51 For instance, if a party mentions «estoppel» in a statement of claim drafted in English, this could mean estoppel under US or English common law; but a German or Swiss lawyer might interpret it under the Latin proverb venire contra factum proprium - that is, no one may set himself in contradiction to his own previous conduct. $5^{2}$

31 Admittedly, difficulties in translating foreign legal concepts can pose a significant challenge. However, it is the parties' responsibility to explain the meaning of foreign legal concepts clearly. Moreover, there is nothing to prevent the FSC from explaining how it understands such concepts when presented by one of the parties. Why not, for instance, speak of a «Swiss estoppel» as understood by the FSC? Also, as the draft Art. $77\left(2^{\text {bis }}\right)$ FSCA CH sets out, an English translation is only needed if one of the parties demands it. The court clerk may thus continue to draft decisions in one of the official languages, and only needs to provide a translation when requested. That said,

50 Opinion of Organisations, 36 et seq.

51 Translated by the author; Ramon Mabillard, Attraktivität des Schiedsplatzes «Schweiz», SZZP 5/2019, 473 .

$5^{2}$ Ibid.; see also Gary B. Born, International Commercial Arbitration, $2^{\text {nd }}$ ed. 2014, 1472 et seqq. 
particularly in international arbitration, it can be expected that parties will regularly avail of this possibility, to assist with recognition and enforcement of the FSC's decision in a foreign country.

From a practical point of view, the fact that federal acts such as the $\mathrm{CPC} \mathrm{CH}$ are increasingly translated into English should substantially facilitate the translation process.53 More specific to arbitration, according to the Federal Chancellery, English translations of the FSCA CH and the IPLA CH will soon be published. Moreover, the translation service of the Federal Chancellery could be very useful in this regard; as could its terminology database (TERMDAT), 54 which is being updated continuously and ensures that English terms are used consistently by the Swiss government. A more creative solution could also be appropriate: assistance from the Swiss Institute of Comparative Law, which is also based at the FSC's headquarters in Lausanne. This institute is home to a wide range of experts on many different legal systems, 55 and the Federal Council is authorised to entrust it with further tasks, such as the translation of decisions. 56

\section{d) Workload at the FSC versus Unemployed Swiss Lawyers?}

33 Third, the FSC stated that as a result of the proposed amendment, the reduced translation costs of the parties could re-

53 See also the classified compilation of the translated Swiss laws into English.

54 TERMDAT Database.

55 www.isdc.ch.

56 Art. 3(3) Federal Act on the Swiss Institute of Comparative Law of 28 September 2018, as amended on 1 January 2020 (SR 425.1). sult in even more objections in civil matters arising from arbitral proceedings. 57 It also fears that in future proceedings, foreign law firms will be instructed to draft legal submissions, and as a consequence, Swiss lawyers will lose important mandates. 58

34 According to the latest available statistics, as per 2017, the FSC handles between 30 and 40 challenges to international arbitral awards and between 10 and 15 challenges to domestic arbitral awards every year.59 Insofar as may be estimated at this point, the number of legal submissions in English should not increase dramatically just because this option becomes available. One might argue that under current law, as German, French and Italian are official Swiss languages, one could expect lawyers from Germany, Austria, France and Italy to be eager to draft objections themselves before they are handed in by their Swiss colleagues. ${ }^{60}$ However, this is clearly not the case.

35 Swiss lawyers thus should not worry that their foreign colleagues will encroach on their field of expertise. The chance of successfully challenging an arbitral award remains at around just 7\% for international awards and around 20\% for domestic awards. ${ }^{61}$ It is therefore unlikely that foreign law firms would draft ob-

57 Rep. Consultation Procedure IPLA CH (2018) (fn. 38), 37.

58 Opinion of Organisations, FSC (37) and University of Lucerne (270); Marco Stacher/Christian Oetiker, Kernpunkte der Revision des 12. Kapitels des IPRG, Swiss Review of International and European Law 2/2018, 222.

59 Felix Dasser/Piotr Wójtowicz, Challenges of Swiss Arbitral Awards, Updated Statistical Data as of 2017, ASA Bulletin 2/2018, 278 and 289.

60 Art. 40 FSCA CH.

61 Dasser/Wójtowicz (fn. 59), 280 and 289. 
jections themselves and then instruct a Swiss lawyer to submit them. As Swiss law is often chosen as the substantive law, it is likely that only Swiss lawyers accustomed to its provisions would dare to challenge arbitral awards before the FSC. This also applies to procedure: that is, how to file the objection with the $\mathrm{FSC}^{62}$ and on what grounds an arbitral award may be set aside. ${ }^{63}$ The FSC's concerns in this regard would thus appear unjustified - at least (insofar as may be estimated) at this time.

\section{e) Cantonal Court Assistance}

Finally, allowing litigation in English before the FSC will not necessarily affect the federal level only. In this regard, one should consider the provision of court assistance to arbitral tribunals by the socalled juge d'appui - that is, the respective judge who renders the assistance. This might relate to the appointment, challenge, removal or replacement of arbitrators; the order of interim measures; or the taking of evidence, among other things. ${ }^{64}$ It is expected that such proceedings will gain increasing importance, especially with regards to the taking of evidence. In the age of big data, when requests are made for whole categories of documents in the form of emails, e-databases and chat histories, proceedings before the juge d'appui will become more crucial than ever.

Arts. 39 et seqq. FSCA CH.

63 Art. 191 IPLA CH (international arbitration) and Art. 393 CPC CH (domestic arbitration).

64 Art. 356(2) CPC CH (domestic arbitration); Arts. 179(2), 180(2), 183(2) and 184(2) IPLA CH (international arbitration).
37 Such proceedings fall within the competence of the cantons. ${ }^{65}$ In this regard, the proposed revisions to the $\mathrm{CPC} \mathrm{CH}$ aim to provide a basis for the cantons to amend their laws to allow for the use of English in proceedings of the juge d'appui (see supra III.2). If they refuse to do so, both the provisions governing domestic arbitration (Arts. 353 et seqq. $\mathrm{CPC} \mathrm{CH}$ ) and international arbitration (Arts. 176 et seqq. IPLA CH) would have to be amended as previously suggested regarding Art. 77(2 $2^{\text {bis})}$ FSCA CH (see supra III.2 and 3.b) to allow for the use of English, at least in arbitral matters.

\section{Conclusion}

38 This contribution has shown that the use of English as a language of proceedings in commercial disputes has become increasingly popular in business hubs around the world (see supra II).

39 In Switzerland, however, the discussion has just begun, at both the federal and cantonal levels (see supra II and III). It has been demonstrated that - at least in appellate proceedings in arbitral matters before the FSC - the use of English as the language of proceedings does not pose problems at the constitutional level; nor are the hurdles too high for its practical realisation.

40 As the revisions to both the IPLA CH and the $\mathrm{CPC} \mathrm{CH}$ aim to facilitate the use of English, it seems appropriate to coordinate these efforts as suggested. By doing so, unnecessary discrepancies should be

65 Art. 3 CPC CH: The organisation of the courts and the conciliation is in the competence of the cantons unless the law provides otherwise; see also Art. 70(2) Const CH. 
avoided, and English could be used throughout the full proceedings, and not merely when filing legal submissions. However, at the moment it seems unclear if the provisions suggesting the use of English before Swiss courts will pass the parliamentary debates, both in context of the revision of the IPLA $\mathrm{CH}$ and the $\mathrm{CPC} \mathrm{CH}$.

41 Nonetheless, it may be expected that the use of English before Swiss courts should enhance the attractiveness of Switzerland as a forum for the resolution of international disputes. However, this will apply only if the full proceedings - from first legal submissions to the final decision can be conducted in English. The Netherlands Commercial Court was an early mover in this regard, and it is hoped that Swiss courts will follow suit. 